TECHNICAL SCIENCES AND TECHNOLOGIES

UDC 621.8

DOI: $10.25140 / 2411-5363-2021-2(24)-43-48$

Jan Semjon, Martin Kočan, Rastislav Demko

\title{
CREATION OF A 3D MODEL OF ROBOT ACTIVITY ASSEMBLY IN THE ROBODK ENVIRONMENT
}

The article describes the creation of a simulation of a robotic training workplace in the RoboDK environment. The workplace is equipped with a two-arm industrial robot Yaskawa SDA 10F, which is equipped with electric grippers Schunk. The workplace also includes a system of two jigs, where the robot translates plastic and metal rollers between the jigs. Jigs can be moved as needed within the robot's workspace. The created simulation fulfills the role of a demonstration program for training students or workers in industry. The article is a publication of scientific and methodical character.

Keywords: robot; programming; RoboDK; welding fixture.

Fig.: 6. Table: 1. References: 10.

Urgency of the research. Today, industrial robots are widespread around the world. The IFR ("International Federation of Robotics") estimates the current number of industrial robots worldwide at 1.64 million. The industrial robotics market is worth $\$ 13.8$ billion [1]. In Fig. 1 shows the number of introduced industrial robots by individual continents until 2019.

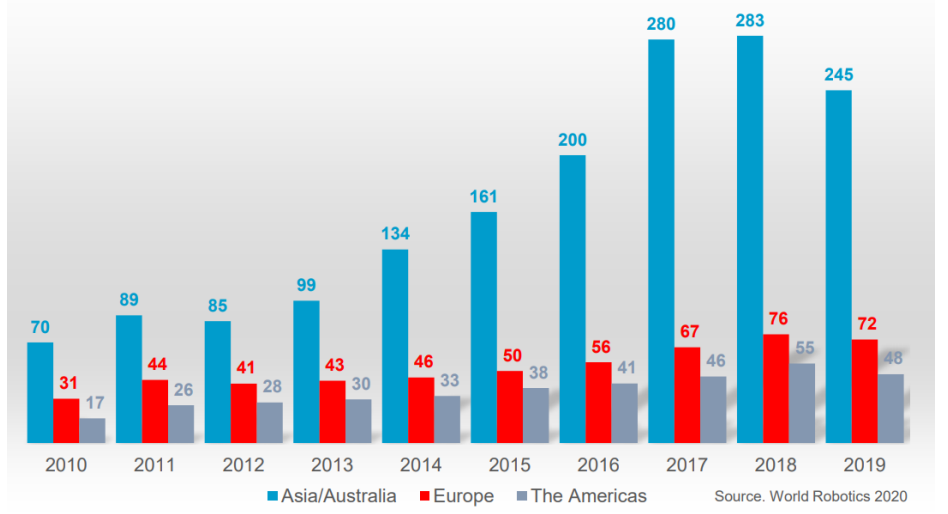

Fig. 1. Annual procurement of industrial robots in the thousands [1]

Target setting. A robot becomes more and more intelligent, better technologically equipped. Robots are a matter of course in almost every handling and technological task. Developing a program for humans is getting easier and faster. Each new line of the company is more modern, more accurate, has a greater load capacity, is easier to program. The interface is more intuitive and easier to navigate. The most common ways to use of industrial robots are technological operations such as spot welding, arc welding, drilling, spraying, milling, drilling ...), handling tasks (pick-and-place, folding and unfolding, packaging, palletizing ...). They all are have great precision and maximum speed. For successful programming of robots and robotic workplaces or their optimization, it is necessary to control off-line programming methods.

Actual scientific researches and issues analysis. Every customer and operator of a robotic workplace wants their robot and production to work $100 \%$. Therefore, it strives to achieve the highest possible speed, the best accuracy, high efficiency. In order to achieve this, it is appropriate to use a suitable simulation environment, with which it is possible to effectively implement offline programming. One of such environments is the RoboDK environment, which has in its database a wide range of robots from various manufacturers [2]. This allows students to improve their competencies during their studies so that they are able to use the acquired knowledge in industrial practice. RoboDK has in its database about 500 types of robots from 50 manufacturers, which makes it a universal and low-cost simulator for industrial robots and their programming. The main reason for using this program was its simplicity and intuitive operation. Off-line programming is relatively easy and fast, which is another advantage when teaching students. The environment of the program is transparent, easy to navigate and not very demanding on hardware.

(C) Semjon J., Kočan M., Demko R., 2021 
Research in the field of creating training workplaces is focused primarily on online work directly at the robotized workplace $[3 ; 4 ; 5]$. Off-line trainings are provided by providers of such trainings in various ways $[6 ; 7 ; 8]$. At our workplace, teaching is carried out on robots of several manufacturers according to the information sheets of individual subjects. In the case of training for technical practice, the training is adapted to their requirements. In order to be able to carry out off-line training on robots from several manufacturers, it was necessary to choose an off-line environment that would allow it. Based on the analysis of off-line environments located at the workplace (Robot Studio, Roboguide, RoboDK), the RoboDK environment was selected.

The research objective. The basic idea of why it was necessary to implement the simulation in the environment was to show students the steps needed to successfully master the environment. There are a total of three different workplaces in the robot's workspace. The workplace, which was selected as a sample, was based on the bachelor's thesis of one of the authors of the article.

General overview of the system. Currently, there is a Motoman / Yaskawa SDA 10F robot in the robotic workplace, which has two end grippers. The right gripper, two-finger, is used to grip the outer cylindrical surface. The left gripper, three-finger, is used to grip the inner cylindrical surface. There are also 3 stations at the workplace where various activities are carried out as part of student training (Fig. 2). This robot falls into the category of serial, angular, industrial robots. It is a two-armed robot, with one arm having 7 degrees of freedom. Together, the robot has 15 degrees of freedom - 14 degrees of freedom thanks to the arms and 1 degree of freedom due to the carousel, which allows the entire robot structure to rotate around its own axis. This robot has a high dexterity, while each arm can perform a different task or work together on the same task. The whole movement takes place on a small floor plan, thanks to which it is advantageous to use it in a small working space $[9 ; 10]$.

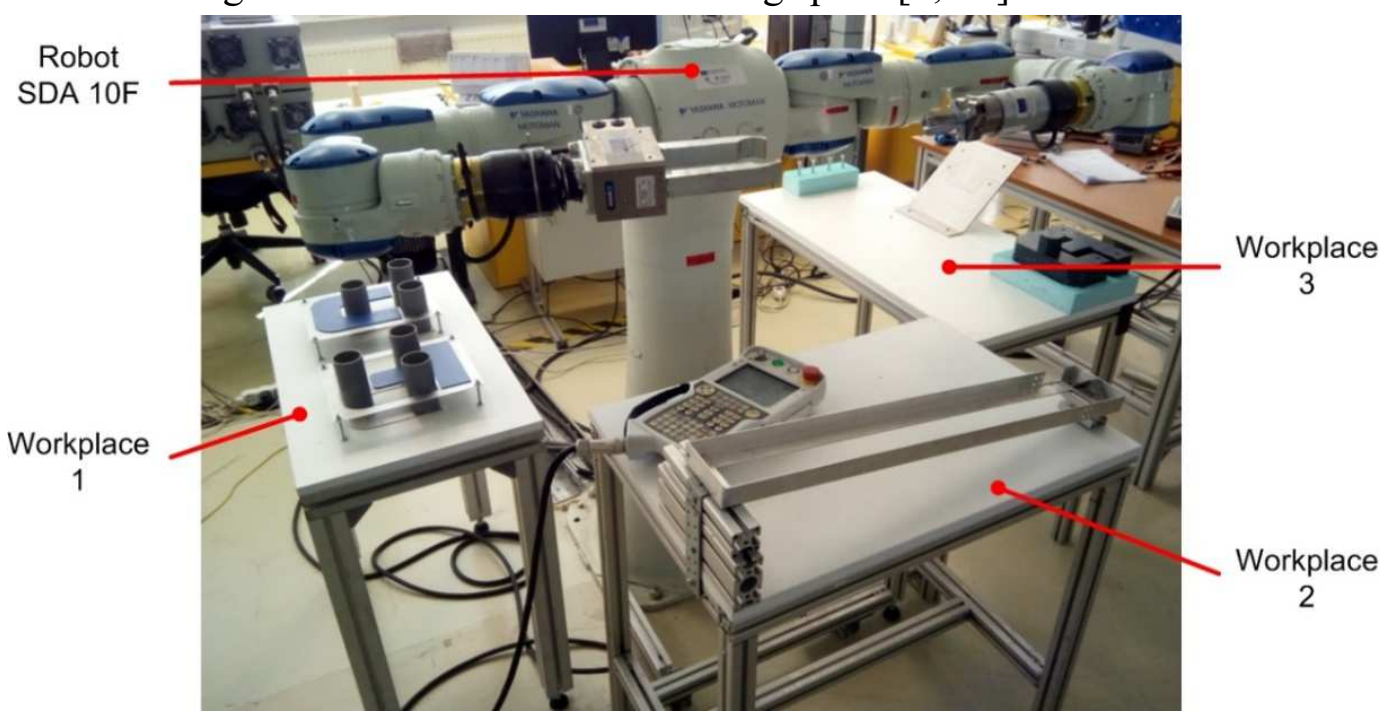

Fig. 2. Yaskawa Motoman SDA 10F

We can find the robot at the Institute of Automation, Mechatronics, Robotics and Production Systems - Technical University in Kosice, in the laboratory marked PK8 / 004. In Table we can see the basic technical data of the robot.

Table - Basic technical data SDA 10F [10]

\begin{tabular}{|l|c|}
\hline Parameter & Value \\
\hline Dimension & $505 \times 1354 \times 505 \mathrm{~mm}$ \\
\hline Weight & $220 \mathrm{~kg}$ \\
\hline Payload & $2 \times 10 \mathrm{~kg}$ \\
\hline Accuracy & $+/-0.1 \mathrm{~mm}$ \\
\hline Number of controlled axes & 15 \\
\hline Location & floor, wall, ceiling \\
\hline
\end{tabular}


TECHNICAL SCIENCES AND TECHNOLOGIES

The mechanical unit of the SDA 10F robot consists of a base, a carousel that can rotate around the base, two arms and flanges at the end, to which end effectors can be connected. The robot is powered by a voltage of $400 \mathrm{~V}$ (using a $230 \mathrm{~V}$ converter). The task of the robot control system, designated FS 100 (Fig. 3), on the basis of the information stored in the memory of the control computer and the information obtained from the internal and external sensors, is to plan the operation of the robot and decide on the individual steps to be performed so as to avoid any mechanical damage. The two-storey structure of the control system is used as the control system, as the robot is equipped with up to 15 drives. This means that the control system is composed of two dimensionally identical cabinets placed one above the other.

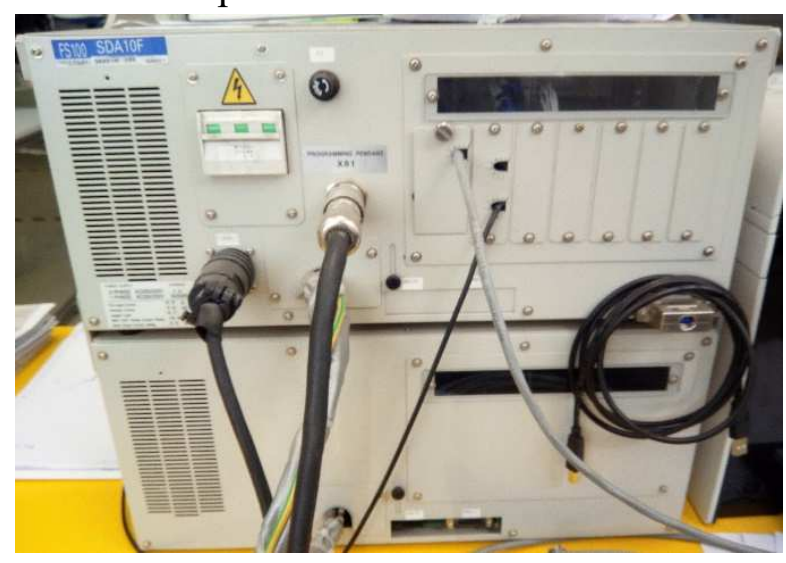

Fig. 3. FS 100 control system

The workplace consists of a work table $560 \mathrm{~mm}$ high made of system aluminium profiles measuring 50x50 mm, a worktop measuring $400 \times 700 \mathrm{~mm}$ and two jigs. The jigs have the shape of the logo of the Technical University in Kosice (shape of the letter T and U) and are made of stainless steel sheet $1.5 \mathrm{~mm}$ thick. The dimensions and shape of the fixtures are shown in Fig. 4.
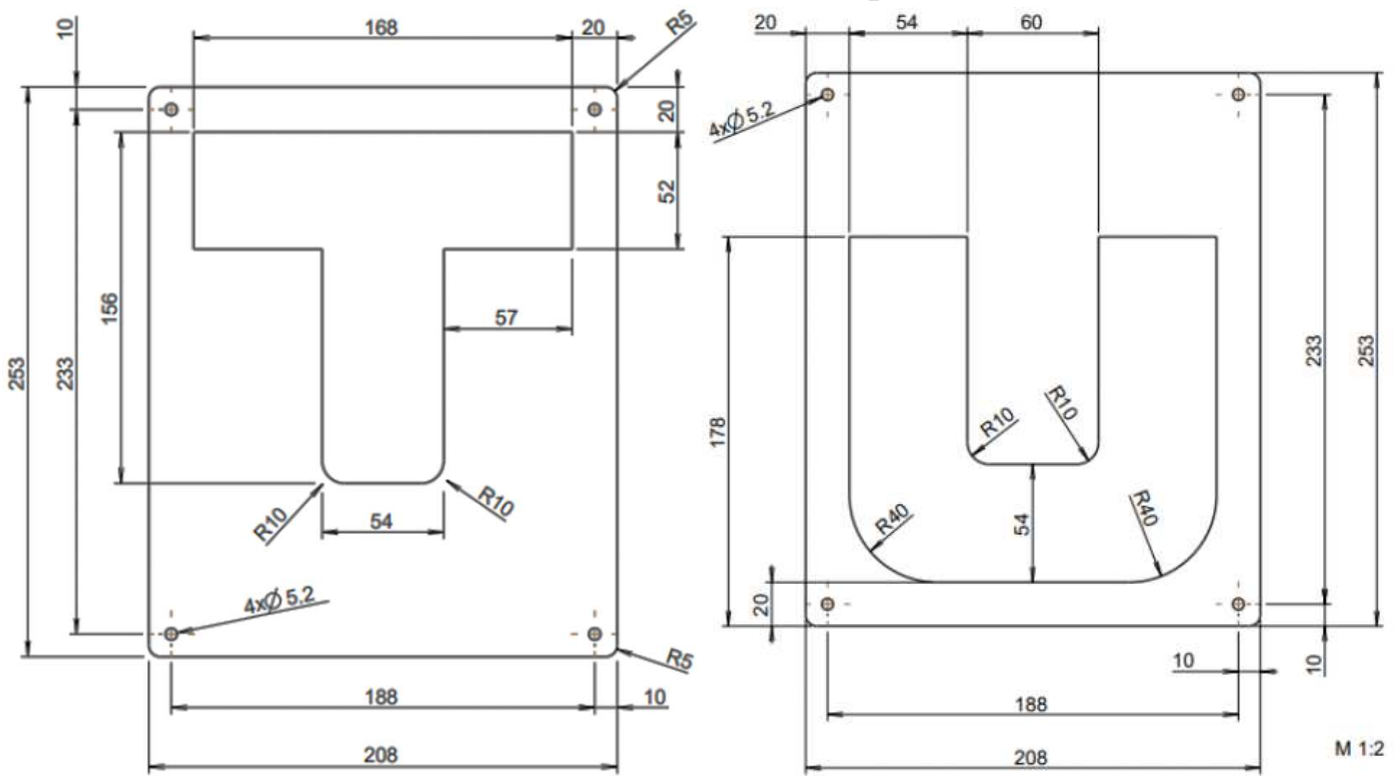

Fig. 4. Fixtures in the form of logo TUKE

The task of the robot is to use two electric grippers from the company Schunk EZN 64 and PG 70 to transfer pipes with dimensions D50x100 mm from one jig to another jig and back.

The process of working in a simulation environment began with selecting a robot from a database. Subsequently, models of electric grippers were imported from the official website of Schunk. A 3D model of the work table, a model of individual jigs and fingers for individual grippers were created in the CAD environment Creo Parametric. The shape of the fingers was chosen so that they were able to grip and store the workpieces in the appropriate positions. 
The modelled components (table, jigs, grippers, fingers and workpieces) were then imported into the RoboDK environment. In Fig. 5 shows individual components with dimensions corresponding to a real workplace.

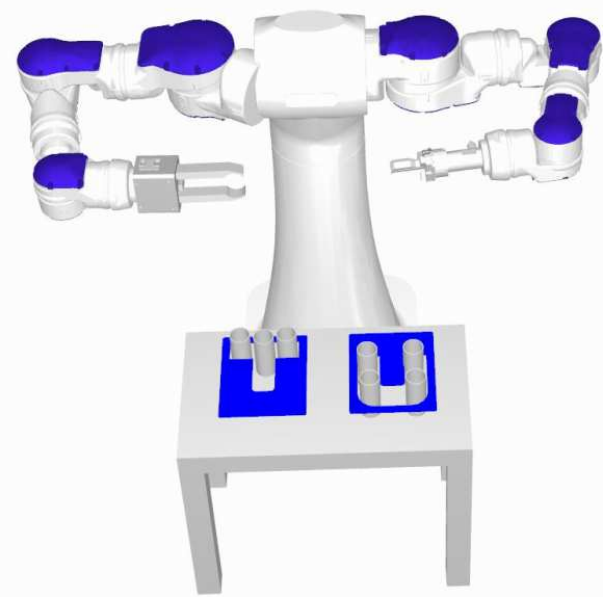

Fig. 5. Workplace in RoboDK environment

The home position of the robot is the starting position for the entire program. In this position, the robot starts and finishes the task. The robot begins to move from the home position, from where the right hand, with a three-finger effector, gradually moves to the roller located in the U - fixture (Fig. 6). Meanwhile, the left hand, with a two-finger effector, moves to the position from which it takes over the roller (Fig. 6). After the left hand takes over the roller, the right hand is moved to allow more space for the left hand. Subsequently, the left hand places the roller in the $\mathrm{T}$ - fixture, Fig. 6c. The left hand moves to the level of the non-acting right hand. Subsequently, the robot returns to the home position and the program for one roller is terminated. In a similar way, the transfer of other rollers from one preparation to another and back is performed. Fig. 6 shows some positions when folding the rollers, Fig. 6 , d shows collision monitoring.
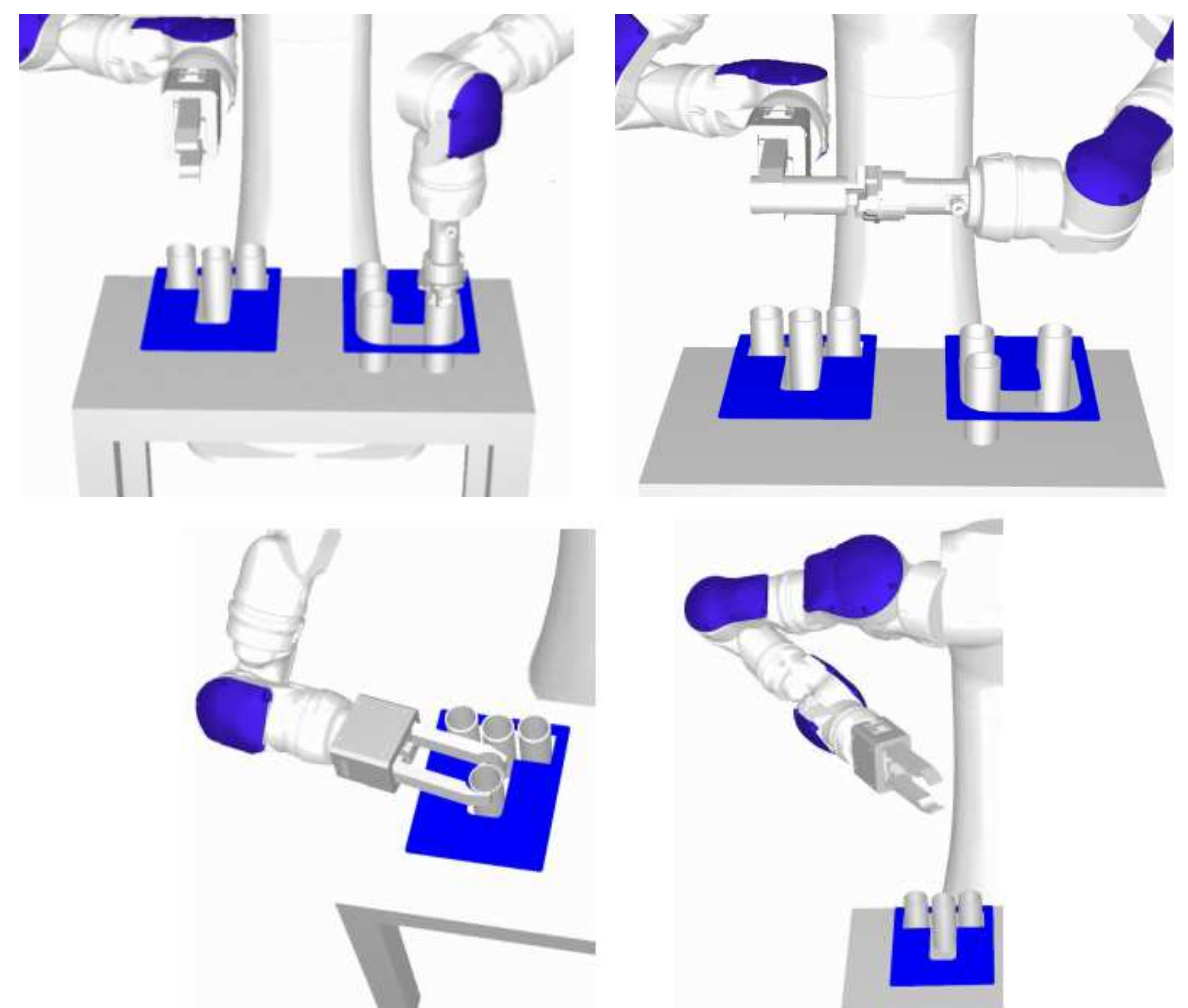

Fig. 6. Robot position when transferring rollers 
TECHNICAL SCIENCES AND TECHNOLOGIES

RoboDK can also monitor collision states in which the robot will not be able to get to the desired position. In this situation, the entire program stops and a warning is displayed on the screen that the robot cannot reach the desired position. The RoboDK environment also contains a function where it generates the entire program according to individual coordinates of points and handling instructions. This program can be uploaded to a real robot, on which the created program is checked.

Conclusions. The article describes an example of designing and creating an off-line program in the RoboDK environment for a robot equipped with two arms. The proposed solution is to serve as a demonstration program, connected to a real robotized workplace. After explaining the procedure of creating a program in a simulation environment, a demonstration in real conditions follows. Subsequently, it is possible to assign individual tasks to students, where the teacher changes the order of translation of the rollers for individual students. After students have created their own simulation according to individual assignments, they can try it in a real workplace. At the same time, it is possible to increase the difficulty of creating a simulation by adding tasks to students at the other two workplaces, which are located in the robot's workspace.

Acknowledgements. This article was created thanks to the KEGA project support: 010TUKE-4/2020 Implementation of new knowledge and innovative approaches to the process of teaching robotics in line with Industry 4 and KEGA project support: 004TUKE-4/2021 Development of innovative teaching materials for learning multi-agent robotics.

\section{References}

1. IFR [Electronic resource]. - Access to the resource: https://ifr.org/free-downloads.

2. RoboDK [Electronic resource]. - Access to the resource: https://robodk.com.

3. Semjon, J., et al., 2020. Design of assembly robotized workplace, In: Technical Sciences and Technologies, Vol. 22, no. 4, p. 35-41. ISSN 2411-5363.

4. Semjon, J., et al., 2020. Design of the handling process at the workplace with ABB robot and modular conveyor, In: Technical Sciences and Technologies, Vol. 21, no. 3, p. 112-119. ISSN 2411-5363.

5. Semjon, J., Demko, R., 2019. Proposal of handling process on robotized workplace with dual arm robot, In: Technical Sciences and Technologies, Vol. 17, no. 3, p. 89-95. ISSN 2411-5363.

6. ABB [Electronic resource]. - Access to the resource: https://new.abb.com/products/robotics/sk/ servis/skolenia.

7. 4robotics [Electronic resource]. - Access to the resource: https://4robotics.sk/services-training

8. Kuka [Electronic resource]. - Access to the resource: https://college.kuka.com.

9. Demko, R. 2019. Design of a handling process at the workplace with a two-armed robot: Bachelor thesis. Kosice: TUKE SjF.

10. Motoman/Yaskawa [Electronic resource]. - Access to the resource: https://www.motoman.com/en- us/products/robots/industrial/assembly-handling/sda-series/sda10f.

УДК 621.8

\section{Ян Семьон, Мартин Кочан, Растислав Демко \\ СТВОРЕННЯ 3D МОДЕЛІ ФУНКЦІОНУВАННЯ СКЛАДАЛЬНОГО РОБОТА В СЕРЕДОВИЩІ RОВОDК}

На сьогодні промислові роботи поширені в багатьох галузях промисловості в усьому світі. IFR («Міжнародна федераиія робототехніки») оцінює поточну кількість промислових роботів у всьому світі в 1,64 мільйони роботів. Ринок промислової робототехніки наразі становить близько 13,8 млрд доларів. Роботи стають все більше розвиненими функціонально, краще технологічно оснащеними, більш надійними. Кожна нова лінія компанії, оснащена складальними роботами є більш сучасною, точнішою, має більшу навантажувальну здатність, ї̈ легше програмувати.

Існуючі дослідження в галузі створення роботизованих навчальних робочих місць оріснтовані насамперед на онлайн-роботу безпосередньо на роботизованому робочому місиі. Тому основна ідея дослідження полягала в тому, щоб показати студентам кроки, необхідні для успішного освоєння середовища RoboDK. Усього в робочому просторі робота є три різних робочих місия. Робоче місие, обране в якості досліджуваного зразка, було створено на основі бакалаврської роботи одного з авторів статті.

У роботі описано створення імітаиії функціонування навчального робочого місия в середовищі RоbоDK. Робоче місие обладнане дворучним промисловим роботом Yaskawa SDA 10F, який оснащений електричними захватами 
TECHNICAL SCIENCES AND TECHNOLOGIES

Schunk. Робоче місие також включає систему з двох робочих зон, де робот перекладає пластикові та металеві ролики. Робочі зони можна переміщувати за потреби в робочому просторі робота. Створене моделювання виконує роль демонстрачійної програми для навчання студентів чи працівників в промисловій галузі. Після створення власної симуляції відповідно до індивідуального задання є можливість ї̈ апробачії на реальному робочому місці. Підвищити складність створення симуляції можна додавши завдання студентам на двох інших робочих місиях, які розташовані в робочому просторі робота. Стаття є публікацією науково-методичного характеру.

Ключові слова: робот; програмування, RoboDK, зварювальний кондуктор.

Рис.: 6. Табл.: 1. Бібл.: 10.

Jan Semjon - Associate Professor, Technical University of Kosice, Faculty of Mechanical Engineering, Department of Production Systems and Robotics (Park Komenskeho 8, 04200 Kosice, Slovakia).

E-mail: jan.semjon@tuke.sk

Number of ORCID - http:// orcid.org/0000-0002-9076-7808

Martin Kocan - Student of Ph.D studies, Technical University of Kosice, Faculty of Mechanical Engineering, Department of production systems and robotics (Park Komenskeho 8, 04200 Kosice, Slovakia).

E-mail: martin.kocan@student.tuke.sk

Number of ORCID - http:// orcid.org/0000-0002-6147-8660

Rastislav Demko - Student of engineering studies, Technical University of Kosice, Faculty of Mechanical Engineering, Department of Production Systems and Robotics (Park Komenskeho 8, 04200 Kosice, Slovakia).

E-mail: rastislav.demko@student.tuke.sk 